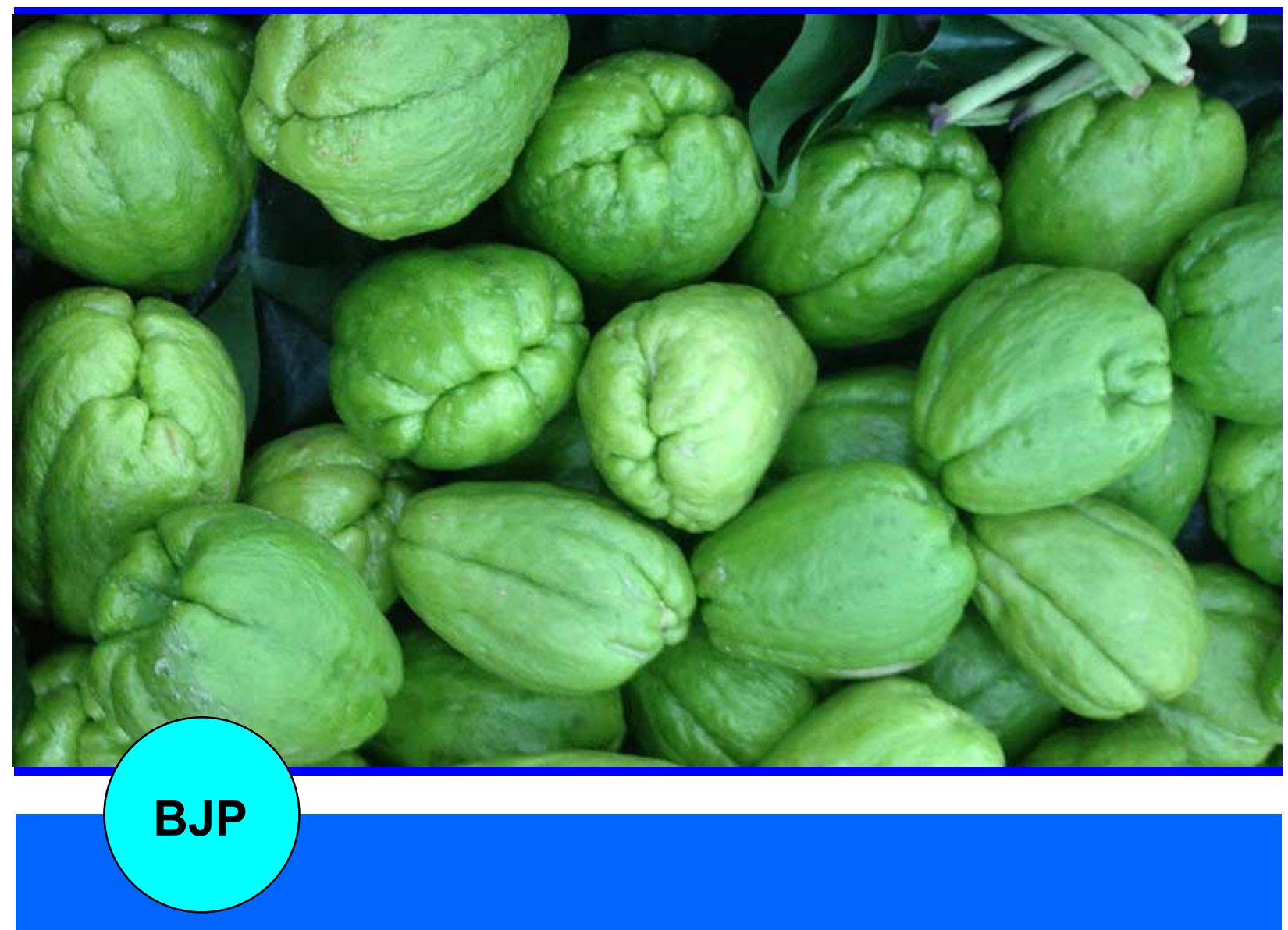

Bangladesh Journal of Pharmacology

Research Article

Antiepileptic and central nervous system depressant activity of Sechium edule fruit extract 


\title{
Antiepileptic and central nervous system depressant activity of Sechium edule fruit extract
}

\author{
Sayeed Mohammed Firdous ${ }^{1}$, Shafique Ahmed ${ }^{2}$ and Samiran Dey ${ }^{3}$ \\ ${ }^{1}$ Department of Pharmacology, Calcutta Institute of Pharmaceutical Technology \& AHS, Uluberia, Howrah, West \\ Bengal; ' 2 Department of Pharmacology, Jamia Hamdard, New Delhi; ${ }^{3}$ Department of Pharmaceutical Analysis, \\ Innovative College of Pharmacy, Greater Noida, Uttar Pradesh, India.
}

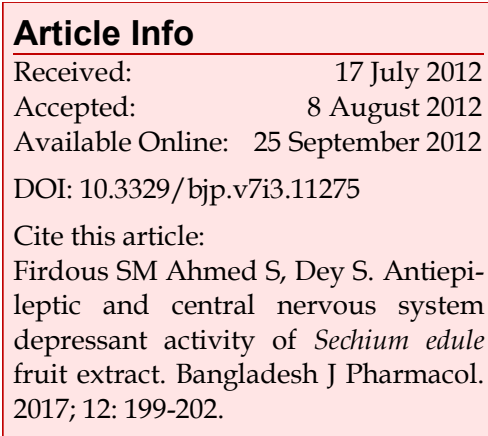

\begin{abstract}
The effect of ethanol extract of fruits of Sechium edule on antiepileptic and central nervous system (CNS) depressant model was studied in rats. The extract $(200 \mathrm{mg} / \mathrm{kg}$ body weight, orally) significantly reduced the duration of various phases of convulsions in both MES-induce seizures and in PTZinduced convulsion. In CNS depressant model, the locomotor activity was also decreased in a dose dependent manner as compared to control group the extract and the rota rod test revealed a significant loss of muscular coordination.
\end{abstract}

\section{Introduction}

Sechium edule, belongs to Cucurbitaceous family vegetable which grows abundantly in the hills of Meghalaya, Mizoram, Manipur, Sikkim and Nagaland. The use of decoctions of leaves and fruits of Sechium edule relieve urine retention, burning sensation during urination and also dissolve kidney stones. It is also use for the treatment of arteriosclerosis and hypertension (Gordon et al., 2000). Different pharmacological studies revealed the diuretic properties, anti-oxidant effect (Ordonez et al., 2006), anti-inflammatory and cardiovascular properties of the $S$. edule. It is also used in severe hypokalemia in pregnancy (Jensen et al., 1986), possess trypsin inhibitor activity (Helen et al., 2006). It has been also reported that the extract of $S$. edule having antimicrobial activity (Adriana et al., 2009). The roots, leaves, stems, and fruits of the plant contain five $O$ glycosyl flavones and three C-glycosyl and were detected by LC-photodiode array-MS (Siciliano and De Tommasi, 2004). The extracts of the seeds of S. edule contain twenty known Gibberellins. Gibberellins $A_{8}$ and gibberlin $\mathrm{A}_{8}$-catabolites are the major gibberellins found in S. edule (Albone et al., 1984).

No major reports on CNS activity of $S$. edule were found. So, in the present study the CNS activities of this fruit were evaluated.

\section{Materials and Methods}

\section{Plant}

Fresh fruits of S. edule were collected from Bangalore and also from Secunderabad. The fruit material was taxonomically identified and authenticated at Regional Research Institute (Ay.), Bangalore, by Dr. Shiddamallayya N. The voucher specimen is conserved under the reference number (RRCBI/MCW/7/2008).

\section{Preparation of ethanol extract}

The fruits of S. edule were isolated, chopped and dried at room temperature for seven days. The dried materials were powdered by using mixer grinder. The powder was first defatted with petroleum ether (60-80 GR) for 72 hours and then the extraction of dried 
powder was done with $99.9 \%$ ethyl alcohol. The yield of dried ethanol extract fruits of $S$. edule was approximately $12.1 \% \mathrm{w} / \mathrm{w}$.

\section{Experimental animals}

Wistar rats of either sex weighing 150-200 g were maintained under controlled tempera-ture $\left(23 \pm 2{ }^{\circ} \mathrm{C}\right)$ and humidity (50 $\pm 5 \%$ ) and $12 \mathrm{~h}$ day and night cycle. Free access to standard pellet diet and water ad libitum were also provided. All the experimental procedures were carried out according to the guidelines of committee for the purpose of control and supervision of experiments on animals (CPCSEA) and approved by the Institutional Animal Ethics Committee (IAEC).

\section{Drugs and chemicals}

Pentylenetetrazole was purchased from Sigma, USA. Phenytoin and diazepam injections were purchased from Ranbaxy, India. PTZ was dissolved in water for injection.

\section{Acute toxicity study}

Acute toxicity study of ethanol extract fruits of S. edule was performed according to the acute toxic class method of OECD guidelines. In acute oral toxicity study mortality was not observed up to $2,000 \mathrm{mg} / \mathrm{kg}$ body weight (OECD 2002).

\section{Maximum electroshock-induced seizures}

In this study, animals were divided into four groups $(n=6)$. Group I: Rats were served as a normal control, received vehicle $(0.9 \% \mathrm{w} / \mathrm{v} \mathrm{NaCl}$ saline, $1 \mathrm{~mL} / 100 \mathrm{~g})$. Group II: Rats were received standard drug phenytoin (25 mg/kg, i.p.). Group III: Rats were received ethanol extract of fruits of S. edule $(200 \mathrm{mg} / \mathrm{kg}$, p.o). Group IV: Rats were received ethanol extract of fruits of $S$. edule (100 mg/kg, p.o).

Inco Electroconvulsiometer model\# 100-3 was used to provide maximal electroshock (150 mA) for $0.2 \mathrm{sec}$ through ear electrodes to induce convulsions. The duration of various phases of epilepsy were observed (Sayyah et al., 2000; Balakrishnan et al., 1998).

\section{Pentylenetetrazol-induced seizures}

The animals were divided into four groups $(n=6)$. Group I: Rats were served as a normal control, received vehicle $(0.9 \% \mathrm{w} / \mathrm{v} \mathrm{NaCl}$ saline, $1 \mathrm{~mL} / 100 \mathrm{~g})$. Group II: Rats were received standard drug Diazepam $(4 \mathrm{mg} / \mathrm{kg}$, i.p.). Group III: Rats were received ethanol extract of fruits of S. edule (200 mg/kg, b.w, p.o). Group IV: Rats were received ethanol extract of fruits of $S$. edule $(100$ $\mathrm{mg} / \mathrm{kg}$ ).

PTZ was administered ( $80 \mathrm{mg} / \mathrm{kg}$, i.p.) $45 \mathrm{~min}$ after administration of saline, standard drug and ethanol extracts of fruits of S. edule. After injection animals were observed for $30 \mathrm{~min}$ and the effect of ethanol extract fruits of S. edule on onset of myoclonic spasm and clonic convulsions were determined (Kulkarni and George, 1999).

\section{Test for locomotor activity}

An actophotometer (Inco, Ambala, India) to evaluate the effect of ethanol extracts of fruits of $S$. edule on locomotor activity of rats. An actophotometer consists of a cage which is $40 \mathrm{~cm}$ long and $40 \times 40 \times 40 \mathrm{~cm}$ and has a wire mess at the bottom. Six lights and six photo cells are placed in the outer periphery of the bottom in such a way that a single rat blocks only one beam. Photo cells are activated when the rays of light fall on photocells.

The animals were divided into four groups $(n=6)$. Group I: Rats were served as a normal control, received vehicle $(0.9 \% \mathrm{w} / \mathrm{v} \mathrm{NaCl}$ saline, $1 \mathrm{~mL} / 100 \mathrm{~g})$. Group II: Rats were received standard drug diazepam $(4 \mathrm{mg} / \mathrm{kg}$, i.p.). Group III: Rats were received ethanol extract of fruits of S. edule (200 mg/kg, p.o). Group IV: Rats were received ethanol extract of fruits of $S$. edule $(100 \mathrm{mg} / \mathrm{kg}$, b.w, p.o).

The beam of light is cut as and when animal crosses the light beam, number of cut offs were recorded for 10 minutes (Goyal, 2006).

\section{Motor co-ordination test (Rota rod test)}

In this study, animals were divided into following groups of 6 rats each. Group I: Rats were served as a normal control, received vehicle $(0.9 \% \mathrm{w} / \mathrm{v} \mathrm{NaCl}$ saline, $1 \mathrm{~mL} / 100 \mathrm{~g})$. Group II: Rats were received standard drug diazepam (4 mg/kg, i.p.). Group III: Rats were received ethanol extract of fruits of $S$. edule $(200 \mathrm{mg} / \mathrm{kg}$, p.o). Group IV: Rats were received ethanol extract of fruits of $S$. edule $(100 \mathrm{mg} / \mathrm{kg}, \mathrm{p} . \mathrm{o})$.

Motor Co-ordination test was conducted using a Rota rod apparatus (Inco Ambala, India). The animals were placed on the moving rod prior to the treatment and the rats that stayed on the rod without falling for $120 \mathrm{sec}$ were chosen for the study. The fall of time of animals of was noted (Kulkarni, 1987).

\section{Statistical analysis}

Statistical analysis of data was done by using the oneway analysis of variance (ANOVA) followed by Dunnet's ' $\mathrm{T}$ ' test. $\mathrm{p}<0.05$ was considered significant.

\section{Results}

The results of anticonvulsant effect of ethanolic extract of fruits of S. edule are shown in Table I and II. In MES induced convulsion in rats (Table I), the ethanol extract of fruits of S. edule $(100 \mathrm{mg} / \mathrm{kg}$, p.o. and $200 \mathrm{mg} / \mathrm{kg})$ significantly reduced the duration of various phases of convulsions. In PTZ induced convulsion in rats (Table 


\section{Table I}

Effect of ethanol extract of fruits of Sechium edule against MES Induced convulsions rats

\begin{tabular}{|c|c|c|c|c|c|c|c|}
\hline \multirow[t]{2}{*}{ Groups } & \multirow[t]{2}{*}{ Treatment } & \multirow[t]{2}{*}{$\begin{array}{c}\text { Dose } \\
(\mathrm{mg} / \mathrm{kg})\end{array}$} & \multicolumn{5}{|c|}{$\begin{array}{l}\text { Time (sec) in various phases of convulsions } \\
(\text { (Mean } \pm \text { SEM) }\end{array}$} \\
\hline & & & Flexion & Extension & Clonus & Stupor & \\
\hline I & Control (Saline $1 \mathrm{~mL} / 100 \mathrm{~g}$ ) & -- & $6.0 \pm 0.6$ & $15.2 \pm 0.6$ & $17.5 \pm 0.8$ & $94.5 \pm 2.1$ & $125.2 \pm 0.9$ \\
\hline II & Standard (Phenytoin) & 25 & $1.7 \pm 0.3 \mathrm{~b}$ & $0.0 \pm 0.0 \mathrm{~b}$ & $10.3 \pm 0.6 \mathrm{~b}$ & $53.8 \pm 1.0 \mathrm{~b}$ & $68.5 \pm 2.0 \mathrm{~b}$ \\
\hline III & Sechium edule extract & 100 & $4.5 \pm 0.4^{\mathrm{a}}$ & $13.5 \pm 0.4$ & $14.3 \pm 0.6^{a}$ & $86.7 \pm 1.4^{\mathrm{b}}$ & $101.7 \pm 2.1^{b}$ \\
\hline IV & Sechium edule extract & 200 & $2.0 \pm 0.2^{b}$ & $8.8 \pm 0.6^{b}$ & $10.8 \pm 0.6^{b}$ & $68.7 \pm 1.1 \mathrm{~b}$ & $76.5 \pm 1.6^{b}$ \\
\hline
\end{tabular}

Data were expressed as mean \pm SEM. Significant at ${ }^{\mathrm{a}} \mathrm{p}<0.05$ and ${ }^{\mathrm{b}} \mathrm{p}<0.01$ when compared to control $(\mathrm{n}=6)$

\section{Table II}

Effect of ethanol extract of fruits of Sechium edule against PTZ Induced convulsions in rats

\begin{tabular}{|c|c|c|c|c|c|c|}
\hline Groups & Treatment & Dose $(\mathrm{mg} / \mathrm{kg})$ & \multicolumn{4}{|c|}{ Onset time in sec (Mean \pm SEM) } \\
\hline & & & Jerks & Clonus & Extensor & \\
\hline I & Control (Saline $1 \mathrm{~mL} / 100 \mathrm{~g}$ ) & -- & $51.5 \pm 1.3$ & $79.2 \pm 1.0$ & $254.0 \pm 1.5$ & Mortality \\
\hline II & Standard (Diazepam) & 4 & $0.0 \pm 0.0^{b}$ & $0.0 \pm 0.0^{b}$ & $0.0 \pm 0.0^{\mathrm{b}}$ & Recovery \\
\hline III & Sechium edule extract & 100 & $60.8 \pm 1.2^{b}$ & $87.2 \pm 0.9 b$ & $269.8 \pm 1.4^{b}$ & Recovery \\
\hline IV & Sechium edule extract & 200 & $75.2 \pm 0.9 \mathrm{~b}$ & $99.2 \pm 1.1^{b}$ & $308.0 \pm 1.6^{b}$ & Recovery \\
\hline
\end{tabular}

Data were expressed as mean \pm SEM. Significant at ${ }^{b} p<0.01$ when compared to control $(n=6)$

\section{Table III}

Effect of ethanolic extract of fruits of Sechium edule (SE) on locomotor activity (actophotometer) in rats

\begin{tabular}{|c|c|c|c|c|}
\hline Groups & Treatment & Dose (mg/kg,b.w.) & \multicolumn{2}{|c|}{ Score (number of cut off were recorded for $10 \mathrm{~min}$ ) } \\
\hline I & Control (Saline $1 \mathrm{~mL} / 100 \mathrm{~g}$ ) & -- & $293.7 \pm 7.2$ & -- \\
\hline II & Standard (Diazepam) & 4 & $13.0 \pm 1.1^{b}$ & 95.6 \\
\hline III & Sechium edule extract & 100 & $136.3 \pm 2.0^{\mathrm{b}}$ & 53.6 \\
\hline IV & Sechium edule extract & 200 & $102.0 \pm 1.7^{b}$ & 65.3 \\
\hline
\end{tabular}

Data were expressed as mean \pm SEM. Significant at ${ }^{b} p<0.01$ when compared to control $(n=6)$

\begin{tabular}{|c|c|c|c|c|}
\hline \multicolumn{5}{|c|}{ Table IV } \\
\hline \multicolumn{5}{|c|}{ Effect of ethanol extract of fruits of Sechium edule on rota rod test in rats } \\
\hline Groups & Treatment & $\begin{array}{c}\text { Dose } \\
(\mathrm{mg} / \mathrm{kg}, \mathrm{b} . w .)\end{array}$ & & \\
\hline I & Control (Saline $1 \mathrm{~mL} / 100 \mathrm{~g}$ ) & -- & $312.5 \pm 2.0$ & -- \\
\hline II & Standard (Diazepam) & 4 & $17.5 \pm 0.8^{b}$ & 94.4 \\
\hline III & Sechium edule extract & 100 & $141.7 \pm 2.4^{\mathrm{b}}$ & 54.7 \\
\hline IV & Sechium edule extract & 200 & $104.3 \pm 1.6^{b}$ & 64.7 \\
\hline
\end{tabular}

Data were expressed as mean \pm SEM. Significant at ${ }^{b} p<0.01$ when compared to control $(n=6)$

II) the ethanolic extract of fruits of $S$. edule $(100 \mathrm{mg} / \mathrm{kg}$ and $200 \mathrm{mg} / \mathrm{kg}$ ) delayed onset of clonus and extensor and produced significant anticonvulsant activity.

In locomotor activity model, significant $(\mathrm{p}<0.01)$ and dose dependent reduction of locomotor activity was observed in rats treated with the ethanol extract of fruits of S. edule (100 mg/ kg and $200 \mathrm{mg} / \mathrm{kg}$, p.o) (Table III). The rota rod test revealed a significant $(p<0.01)$ loss of muscular coordination (Table IV). Thus, the ethanol extract of fruits of $S$. edule possessed CNS depressant activity as indicated by the significantly reduced, motor coordination and spontaneous motor activity. 


\section{Discussion}

The MES induce convulsion model one of the widely used anticonvulsant animal model. This model is helpful for determination of tonic-clonic seizures (Loscher et al., 1988; Oliveira et al., 2001). The repeated electrical pulses by the electroconvulsiometer to neurons produce a standard epileptic characteristic. In this present study, the ethanol extract of fruits of $S$. edule $(100 \mathrm{mg} / \mathrm{kg}$ and $200 \mathrm{mg} / \mathrm{kg}$ ) significantly reduced the duration of various phases of convulsions in MES induce convulsion.

Pentylenetetrazole (PTZ) blocks the picrotoxic binding site of GABA type A receptor and interfere with the GABA neurotransmission, produce convulsion (Ramanjaneyulu and Ticku 1984). Benzodiazepines and phenobarbital prevent PTZ induced seizures by increasing the GABA neurotransmission. The ethanol extract of fruits of S. edule (100 and $200 \mathrm{mg} / \mathrm{kg}$ ) delayed the onset of convulsion and produced significant anticonvulsant activity. The ethanolic extract of fruits of S. edule (100 and $200 \mathrm{mg} / \mathrm{kg}$ ) decreased the locomotor activity and also produce loss of muscular coordination. Thus, the ethanol extract of fruits of $S$. edule possessed CNS depressant activity as indicated by the significantly decrease in motor coordination and spontaneous motor activity. This CNS depressant activity may be due to the phytochemicals present in the ethanol extract of fruits of S. edule.

\section{Conclusion}

The result suggests that the ethanol extract of fruits of $S$. edule posses anticonvulsant and CNS depressant activity.

\section{References}

Adriana AL, Roxana M, Ordonez, Iris CZ, Maria II. Design and quality control of a pharmaceutical formulation containing natural products with antibacterial, antifungal properties. Int J Pharmaceutics. 2009; 378: 51-58.

Albone KS, Gaskin P, MacMillan J, Sponsel VM. Identification and localization of gibberlins in maturing seed of cucurbit Sechium edule. Planta Springer-Verlag. 1984; 162: 560-65.

Balakrishnan S, Pandhi P, Bhargava VK. Effects of nimodipine on the efficacy of commonly used anti-epileptic drugs in rats. Ind J Exp Biol. 1998; 36: 51-54.

Gordon EA, Guppy LJ, Nelson M. The antihypertensive effects of the Jamaican Cho-Cho (Sechium edule). West Indian Med J. 2000; 49: 27-31.

Goyal RK. Practicals in pharmacology. 5th ed. Ahmedabad, B.S. Shah Prakashan, 2006, pp 121-22.

Helen JL, Vitor MF, Clarice L. Low molecular weight squash trypsin inhibitors from Sechium edule seeds. Phytochemistry 2006; 67: 362-70.

Jensen LP, Lai AR. Chayote (Sechium edule) causing hypokalemia in pregnancy Am J Obst Gynecol. 1986; 5: 1048-49.

Kulkarni SK. Hand book of experimental pharmacology. $3^{\text {rd }}$ ed. New Delhi, Vallabh Prakashan, 1987, p 22.

Kulkarni SK and George B. Significance of long-term potentiation in cognitive functions and epilepsy. Ind J Pharmacol. 1999; 31: 14-22.

Loscher W, Schmidt D. Which animal models should be used in the search for new antiepileptic drugs? A proposal based on experimental and clinical consideration. Epilepsy Res. 1988; 2: 145-81.

Oliveira FA, Almeida RN, Sousa MFV, Barbosa-Filho JM, Diniz SA, Medeiros IA. Anticonvulsant properties of Nsalicyloyltryptamine in mice. Pharmacol Biochem Behav. 2001; 68: 199-202.

Ordonez AA, Gomez JD, Isla MA. Anti-oxidant activities of Sechium edule (Jacq.) Swartz extracts. Food Chem. 2006; 97: 452-58.

Ramanjaneyulu R, Ticku MK. Interactions of pentamethylenetetrazole and tetrazole analogues with the picrotoxinin site of the benzodiazepine-GABA receptorionophore complex. Eur J Pharmacol. 1984; 98: 337-45.

Sayyah M, Valizadeh J, Kamalinejad M. Anticonvulsant activity of the leaf essential oil of Laurus nobilis against pentylenetetrazole and maximal electroshock-induced seizures. Phytomedicine 2000; 9: 212-16.

Siciliano T, De Tommasi N. Study of flavonoids of Sechium edule (Jacq) Swartz (Cucurbitaceae) different edible organs by liquid chromatography photodiode array mass spectrometry. J Agric Food Chem. 2004; 52: 6510-15. 